\title{
Democracy Establishment on Regional Head Election Observed from the Constitutional Law Perspective in Indonesia
}

\author{
Sugianto \\ IAIN Sheikh Nurjati Cirebon, Indonesia \\ sugianto.iain.crb@gmail.com
}

\begin{abstract}
The amendment of the 1945 Constitution had opened space for democratic realization process at local level. In Article 18 paragraph (4) mentioned that governors, regents and mayors respectively as the heads of provincial, regency and municipal elected democratically. The local elections were carried out simultaneously by the people show democratic electoral system embodiment. To analyze the phenomena, this study uses a qualitative method, which the data source derived from primary and secondary data. Primary data is data obtained from observations in field, while secondary data obtained from literature or news about the regional head elections. The results showed that in a democratic election, a guarantee of freedom is an absolute and normative requirement. However the normative requirements sometimes ignored either by contestants or supporters. Therefore, the presence of the Constitutional Court is very important for democracy and constitutionality of local elections. In the local elections, the Constitutional Court has the authority to resolve the election results dispute. Although the existence of the Constitutional Court is important, but to resolve the dispute over local elections, researchers assume about the necessary establishment judicial elections at any stage or process level.
\end{abstract}

Keywords: 1945 Constitution, Local Election, Democracy, Constitutional Court

\section{Introduction}

Political changes in Indonesian constitutional develop fundamentally since the reform movement rolling in 1998, which depose President Soeharto as President of Indonesia. The reform movement become so monumental stake for doing a very fundamental changes, both in politics or constitutional system. One of the important changes is in terms of regional governance and a democratic political system implementation at local level. A changes in constitutional system happens when demands of the 1945 Constitution changes idea, which in the New Order was very sacred, finally responded by People's Consultative Assembly. People's Consultative Assembly that still serves as the highest state institutions, and that an institution which often referred as sovereign folk and the Indonesian people embodiment eventually really realize the people demands in reform movement, namely amending the 1945 Constitution. Amendment which done by People's Consultative Assembly to the 1945 Constitution carried out four times, namely in 1999, 2000, 2001, and 2002. In political changes context at the local level, the 1945 Constitution amendment has opened space for democratic process realization at local level. This can be seen in Article 18 paragraph (4), which states that the Governor, Regents and Mayors as the respective heads of provincial, regency and municipal elected democratically. The emergence of these provisions have made changes which is fundamentally to the system and constitutional norms, because previously regional head elections are not regulated in the 1945 Constitution.

Prior to changes or amendments to the 1945 Constitution, rules against elections translated according to political interests of the regime. No wonder if at that time, President Soeharto has greater authority to elect regional heads from candidates nominated by the Regional Representatives Council. In other words, the central government in the New Order Era has a very strong power dominance over local government. Soeharto regime have full control of the regional heads at all levels, in accordance to Law No. 5 of 1974 on the Regional Government Principles. The regional head appointed by the President, which the election mechanism in Parliament also controlled by the President. Unanimous shifting the New Order Era to reform, and amending of the $1945 \mathrm{~m}$ Constitution, elections era which not democratic has shifted towards more democratic. Today, both governors, regents, and mayors should be elected democratically. Surelly the 
regional head elections mechanisms changes does not happen immediately when the new order fell in 1998, because the setting of regional head elections which democratic set at the second 1945 Constitution amendment, which in 2000. At early reform era (1998-1999), the setting of regional head elections regulated in Law No. 22 of 1999 on Regional Government. The existence of this law represents a milestone in the governance reforms field in areas with a strong decentralization principle, including Parliament position which also strengthened. On Law No. 22 of 1999, although governors, regents and mayors are still elected by Parliament, but this law is considered more democratic than the previous, namely Law No. 5 1974. The reason in Law No. 22, 1999 there is no President authority to intervene in regional head elections, due to be submitted to the electoral process in a democratic parliament. However, a regional head election system by Parliament instead have no weaknesses. In practice this system is contrary to democracy essence, because in fact appears money politics in rallying support in parliament so that a person can internally elected to be head area.

The regional head election by parliament when it also often rated as an election which leaving the people aspirations, because people do not have an important position in selecting candidate process for the leader. Candidacy or the election process is fully the political parties authority which have representatives in Parliament, so that it can be ascertained that parties which hold the majority vote in Parliament has the legitimacy and power to nominate its cadres and opportunities these cadres to elect is a very large, though the cadre qualified and have the ability to lead or not. Now regional head election re-entered a new era since Law No. 22 of 1999 amended by Law No. 32 of 2004. In Law No. 32 of 2004 regional head elected directly by the people. In terms of who is entitled to nominate, regional head candidates nominated by a political party, or a political parties coalition and individual candidates (independent). Provision of independent candidates occur after the Constitutional Court allow for independent candidates through a Judicial Review on Law No. 32 of 2004 and the House of Representative Law No. 32 of 2004 into Law No. 12 of 2008. The implementation of local elections is considered compatible with the Indonesia democracy system, because people given broad authority to directly elect regional head candidates whom they wish (Prihatmoko, 2005). The direct election system by the people, although not a perfect system, but this system is still considered better than the system whichever applies previously. Direct election systems by the people indeed still leaves some issues, among others costly and still more likely to put forth corrupt regional head. The huge costs incurred in elections, generally a motive which encourages elected regional head to return expenses capital incurred during the nomination. ${ }^{1}$ Therefore needed strict regulation to resolve the issues.

In addition, the implementation of direct/local elections in some areas also generates conflicts between supporters of prospective head region (Nas, 2015; and Fattah, 2008; and Alihar, 2012). In general, these conflicts arise because of the dissatisfaction of the results of the counting. Therefore, the existence of the constitutional court deems important, because based on the amendment 1945 Constitution, the purpose of the establishment of the Constitutional Court one of which is to resolve election disputes. In other words, that the duties and functions of the Constitutional Court have been stipulated in the Constitution, also have benefits in building a democracy that is based on law. Trully the study of the elections related to democracy and legal aspects been done by some researchers. As with Tjiptabudy (2014) were also raised about the elections, but the research is evaluated the election law and election rearrangement enforcement, which previously been considered not ideal. Likewise with Lay (2007) whose study is only limited to the impact of direct elections aspects for democracy deepening and not go into the legal aspects. The other researcher, namely Hakim (2011) only give democracy description which hold through the election mechanism. in other words, from a few studies that have been reviewed, that researchs has not investigated yer about democracy enforcement in the regional head election seen from the constitutional law perspective in Indonesia.

\footnotetext{
1 See "Evolution of Regional Head Election System in Indonesia". Source: http://politik.news.viva.co.id/news/read/542375-evolusi-sistem-pemilihan-kepala-daerah-di-indonesia [Accessed: January 30, 2016].
} 


\section{Literature Review}

Amendment to the 1945 Constitution, particularly with arrange about regional head elections democratically, is in accordance with the Hardiman (2009: 139) that the constitutional guarantee for public spaces or autonomous civil society is inherent in democratic constitutional state law. In other words, a democratic constitution, in this case the constitution, giving the space and freedom for people to choose the compatible regional head beliefs. The direct regional head elections by the people is very important in a democracy political system, because literally democracy by Sartori (1987: 5) is the "Government of, by, and for the people. Democracy is a government form where the rights to make political decisions are used directly by any citizen who actualized through the procedure of majority rule, commonly known as direct democracy." Normatively regional heads elected from the majority vote of people will have a sense of responsibility towards the people, including in decision-making. Majority context in a democracy by some experts (Mayo, 1960: 70; and Strong 1973: 12) intended for political decision-making or policy that is based on a majority of people's representatives are selected and monitored effectively by the people and accountable to the people. A democratic system by Sartori (1987: 5) characterized by: (1) broad political participation, (2) healthy political competition, (3) the power circulation which is maintained, managed, and periodically, through the electoral process, (4) effective power supervision, (5) the majority will recognition, and (6) the existence of a political manners agreed in society. Perceived a variety of these characteristics, the government power is limited and not right to act arbitrarily against its citizens, these restrictions listed in the constitution.

Meanwhile Dahl (1978: 7), suggests that the democracy identity is the government responsiveness continuously to preferences or citizens desires in the country. As some of the conditions that must be fulfilled among others : (1) freedom to form and join organizations, (2) freedom of expression, (3) the right to vote in elections, the right to hold public office, (4) the leaders right to compete for support and vote, (5) the alternative sources availability of information, (6) elections which free and fair, and (7) the existence of escrow that public policy depend on election vote and ways of others preferences delivering. Changes in regional head elections mechanism, which previously by Parliament and then be by the people, is a consequence of democratization happening in Indonesia. Democratization itself according to some experts (Beetham, 1993: 55) is defined as a regime changes process from authoritarian or dictator who does not provide opportunities for participation and freedom to the government that gives the higher degree of chance participation and freedom. Thus the citizens' participation in political activities is one of provision of the democratization realization in a country, including how citizens or civil society groups are involved in the political process of policy making, including the National Security Draft Bill. Democratization is a practice or democracy principles in any political activities of the state. The democratization goal is characterized by the democratic political life formation. Winarno (2007: 97) argues that democratization refers to the changes process towards a democratic government system. The government's openness and the public engagement in political process is a democratic government identity. As a central theme, democratization has become the studies object which has very broad discussion. Democratization by Tilly (2000: 16) is a regime changes, this view appeared because he saw that the "increase in state capacity is not sufficient for democracy to obtain because capacity can be used to oppress citizens rather than to protect them. "that's why later he revealed that the decreasing autonomy of major power centers is one of the requirements of the democratic transition. This view of "decreasing autonomy" itself supported by Demetriou (2009: 440), which revealed that "Decreasing autonomy can be regarded as a real mechanism (multiply realizable, of course) of Democratization."

\section{Methodology}

This study uses a qualitative method. The data source is divided into two types of data sources, namely primary and secondar. Primary data is a data obtained directly through interview and observation in the field. Secondary data were obtained through documentation relevant to this study, literature or news about the democracy enforcement in election. Interviews were conducted with informants who are experts on politics, namely Yusa Djuyandi from Padjadjaran University. The selection of informants was based on purposive technique, where the informant deemed to know about the dynamics that occur in local elections. Observations carried out research object namely activities in the election form in Indonesia. While the documentation analysis made to various documents relating to the democracy enforcement in 
election. Furthermore, the collecting data process in this study be adapted to the research type. The data collected in this study, namely in the form of words, actions, documents, situations, and events that can be observed. The validity data test in this study is done through Triangulation which is a data validity testing technique which is done by checking correctness of the data obtained by researchers in other parties who can be trusted. To maintain the validity of the data or research, efforts that based on the triangulation principles. In this study triangulation conducted to data sources, as well using a variety of supporting reference to prove the data which has been found in research such as: recording, photographs or other documents that support.

\section{Discussion and Analysis}

Election and Democratic Political System: A democratic political system characteristic lies in democratic order that underlies authorities so the democracy elements not only become state norm but empirically work in accordance with democracy corridors. A democratic political system eventually be an option though requires a number of preconditions and prerequisites are not easy to fulfilled because of some factors such as citizens education level, people's education and political awareness level, the power organizers commitment to create a democratic political system, until the existence law regulation factor that can be an instrument for democratic political system implementation. Theoretically, Diamond, Juan and Seymour (1990: 6-7) defines democracy as a government system that has three (3) requirements, namely:

- There should be competition between individuals and organized groups for all government positions. This should take place through regular and fair elections.

- Political participation in the selection of leaders and policies should include, in principle, all adults.

- Some basic civil and political liberties, such as freedom of expression and freedom to form and join organisation, should be respected.

From three (3) conditions, if regional head election intended to establish a democratic government, so the contestant must be open to all citizens who are eligible regulated through legislation. The contestants (election participants) strive in a fair and sportive. The contestants also prohibited from using force ways or violence to force a person to vote on a particular contestant. Law No. 32 of 2004 on regional governance as amended into Law Number 12 of 2008 about local government, citizens who have the right to vote should also involved given their vote in electoral process. Citizen participation in electoral expected to be high so as the election result has strong legitimacy. However, the citizens participation in vote have to stay within the political and civil freedom corridors, without affraid of intimidation, still have a sense of security. The election contestants/ participants or fellow citizens have to respect the political and civil freedom to fellow contestants nor against fellow citizens. As long as there is no guarantee against this freedom, then the election will far from democratic. However, the normative requirement sometimes overlooked by the contestants as well as by its proponents so that a variety of fraud elections marked, and this certainly is a threat to democracy. Regional Head Election be told democratic if it fulfilled several requirements, including requirements as well apply to the legislative elections in general, namely:

- The presence of universal rights recognition. All the citizens who has the right to choose, not allowed discriminated against on the ideology and political basis

- The existence of voters citizen aspiration pylurality so that citizen have political aspirations channel alternative choices.

- Democratic political recruitment mechanisms availability

- The existence of voters freedom of to vote their choice

- The existence of an independent voters committee

- The existance contestants discretion to healthy compete

- An honest counting votes

- Bureaucratic neutrality

(Goodwin-Gill, 1999: xxii-xxvii)

In democracy, all parties should uphold the values of honesty, respecting others, and obeying rules. In regional head elections certainly no candidates who want to lose, all want to win, but like the game, in the end there will be only one pair of candidates who will be the winner. Of course, winning should not be 
arbitrary, the loser can not be angry with a variety act. If you feel unfairly treated and have enough evidence that there was fraud arising from the dispute, then submitted to the Indonesian Constitutional Court.

Uphold The Democracy and Regional head election Constitutionality: Informant said that "Election is the people sovereignty implementation, as a form of democracy implementation consistency, so that the state establish an institution or committee that organizes the elections, including regional head elections." There is one thing higly vulnerable during the election implementation namely election results dispute. High state institutions as well as Article $24 \mathrm{C}$ of the 1945 Constitution which authorized to settle the election result dispute is the Constitutional Court. The Constitutional Court put forth not only to maintain and uphold the constitution, but also to uphold democracy. In the regional head elections, the Court has authority to resolve election results dispute, it is stated in Article 24 C of paragraph (1) The 1945 Constitution, namely: "The Constitutional Court has authority to adjudicate on first level and lastly which has final decision to verify legislation under the Constitution, to determine the state institutions authority dispute whose authorities granted by the Constitution, to determine political parties dissolution, and to decide disputes the general election results. "In terms of determine the regional head elections dispute, legally the Constitutional Court authority, also mentioned in Article 236 C of Law No. 12 of 2008 on second amendment of Law No. 32 of 2004 about Regional Government, namely that the election dispute authorities given to Constitution Court. basically in every regional, both provinces, districts and cities according to the 1945 Constitution only has "Regional Head" namely 'governor' for the provinces, 'Regent' for the district, and the 'mayor' for the city. In regional head recruitment perspective on article 18 paragraph (4) The 1945 Constitution only done democratically and not using direct principle.

As regional head elections implementation (governors, regents, mayors) which mandated in Law No. 8 2015, as amendment from Law No. 1 of 2015, that the regional head election effectiveness carried simultaneously at the first time dated December 9, 2015 in Indonesia. Despite a pro and contra about the readiness of simultaneously the Regional Head Election Implementation, but the General Election Commission, the Election Trustee and the Honorary Board of Election have demonstrated the readiness of the democracy implementation in Indonesia. Thus the constitutionally or legal regulations state has set and commissioned a number of institutions or the state commission to hold elections and regional head election, starting from the preparation stage to the post-events stage, such as the possibility of a lawsuit over the regional head elections results. Regional head election can not be avoid from democracy transition situation, because regional head election directly began only after the amendment to the 1945 Constitution. The regional head elections were originally selected by the representation principle, namely through Parliament, and change become direct election is a drastic changes, because the people are directly faced with the decision to vote. Quantum of change in the regional head election, certainly will bring positive and negative impacts. The positive impact, in fact efforts on maturing society in a democracy, both in choosing their leaders, as well as determining policy leaders direction within the framework of realizing common prosperity. This process if escorted by compatible instrument, independent and integrated organizer, will put forth the leader and policies that fulfilled the principles of "legal, legitimate, and competence".

Dispute Resolution: Implementation of the local elections sometimes do not always run smoothly, according to the informant this was due to the dissatisfaction of certain candidates and their supporters on the result of vote counting. Some sense of dissatisfaction occasionally acted in a fit of anger, which then often triggers horizontal and vertical conflicts. Emergence of uncontrolled regional head elections violation, and even can not be resolved at any stage regional head elections implementation process, raises idea to established the regional head election in every area. Regional head election justice intended as a solution or problem solving of disputes on every stage of regional head election process, so that every stage has legal certainty. According to informant "Judicial for the elections is also believed can minimize the occurrence of violence, because the local election dispute is resolved through legal channels which are independent." Over time occured argument struggled when appeared the idea to establish a special electoral court. This idea reap the pro and contra among practitioners and academicians. Several fundamental reasons about the idea to establish the Special Tribunal Electoral expressed by Elections Trustee, Bambang Eka Cahya Widodo namely many election violations cases which administratively and contains criminal element and Constitutional Court position as if like a "wastebasket" because all the issues electoral dispute disembogue to it. This is 
implication of ineffectiveness electoral violations handling cases mechanism at stage before rolling to the Court. $^{2}$

The fact that happened on field shows that every stage of the electoral process is still vulnerable to be sued to the judiciary, because things which decided by the authority institutions, such as the General Election Commission, the Election Trustee and the Honorary Board of Election, on that stage considered not provide assurance. In other words, provisions on election results by these institutions vulnerable to be sued by the losing candidates. Therefore, other Constitutional Court granted by the 1945 Constitution to resolve the election results according to article $24 \mathrm{c}$, it is suggested that there is also the judiciary which can solve disputes or violations on stage regional head election process. Proposed that the Constitutional Court since early 2014 should nevermore to solve regional head elections dispute, that matter must returned to the Supreme Court in order to resolve the dispute of the results governors, regents, mayor elections result as regional head. The mechanism of electoral dispute resolution can be done in two ways: through formal and informal lane. EDR can be a prosedural lane, namely through the courts or some sort of special formation committe which handle elections issues and / or through negotiation. In law enforcement settlement general election dispute must be done in five (5) ways:

- Examination by the general election commision (proposed in honorary

- board of elections and / The elections trustee).

- Need to establish special courts and / special judges to handle objections of election disputes.

- The election issues completion submitted to the constitutional court.

- Issues completion by the Supreme Court for governor, regents/mayors election dispute, and

- Completion of legislation elections dispute/ the president\&vice president by the Indonesian Constitutional court.

The idea of the judicial elections establishment, which will handle election violations at every stage of process, considered necessary and relevant when confronted with political reality which shows many election violations that can not be solved by existing institutions. But the establishment of this court also still need to maintain the Constitutional Court as an institution of justice that resolve disputed election results for the House of Representatives, Regional Representative Council, Regional People's Representative Assembly, and the Election of the President / Vice President. The judiciary importance to determined and resolve elections dispute become important when many violations that can not be resolved by the General election Commision. In a political perspective, the idea to establish judicial elections at any stage or level of process, considered rational and realistic. But in a juridical terms this idea will remain faced with Article $24 \mathrm{C}$ paragraph (1) of the 1945 Constitution, which stated the authority to determine elections result dispute is on The Constitutional Court. These conditions later showed question whether it is still possible to establish another judicial commision which given the special authority to determine election violations? that potential general elections issues could classified into 3 groups as an electoral administration, criminal acts and election results disputes violations. Topo Santoso confirms that a dispute in organizing an election is an election administration violations or dissatisfaction case over the election organizers decisions "this matter the Honorary Boards of Elections Authorities (DKPP). ${ }^{3}$ Therefore the term controversies about the elections results dispute for the Parliament, Regional Representative Council, Regional People's Representative Assembly and the President / Vice President, in the 1945 article 24 c paragraph 1, is a part that should resolved by the Constitutional Court. According to writer opinion that the regional head elections results dispute completion (Governor, Regent / mayor as the head of the region), since the enactment of Law No. 12 of 2008, article 236 c, should be returned to the Supreme Court, and no longer the court authority.

\footnotetext{
2http://www.kompasiana.com/rizahakiki/tanggapan-terhadap-ide-peradilan-khususpemilu_551fbb90a333119941b65b64 [accessed on February 13, 2016]

3 Topo Santoso, a paper titled controversies results of the elections presented at a roundtable discussion on the Constitutional Court on 24 March 2011.
} 


\section{Conclusion}

The regional head elections implementation, since elected by Parliament or chosen by people directly, has weakness and advantages. The advantages of direct regional head election are:

- Direct democracy will be able to run better, so that the meaning of people sovereignty will seem real;

- Through direct regional head election, people vote to be very valuable. Thus the people interests gained greater attention because of the direct regional head election implementation and democratic;

- The democratic processes development in civil society enforcement in social life and regional governments will increase, because direct regional head election by the people will take effect in a transparent and responsible, so that will have an impact to the society political education improvement;

The weakness of direct regional head election:

- Requires a high cost because the candidates must campaign to face the electorate directly, both physically (door to door) and through the mass media;

- Regional head figure elected directly by the people in running the goverment can be received strong support from the people and the Parliament which people refresentative.

In order to resolve the election results dispute appear the idea to establish the electoral court, will handle the election violations at every stage of the process. This court is necessary and relevant when confronted with political reality which shows many election violations that can not be solved by existing institutions. However, although there is a judicial institution election but the existence of the Constitutional Court is still needed, as the judicial institution resolve election results disputed for the House of Representatives, Regional Representative Council (Senate), and the Election of the President / Vice President (Election). For the development of science, is expected in the future there will be another study that analyzes the effectiveness of judicial elections, as seen from the viewpoint of law and politics.

\section{References}

Alihar, F. (2012). Disparitas Regional dan Konflik Pilkada Aceh 2012. Jurnal Penelitian Politik, 9(2), 23-34.

Beetham, D. (1993). Liberal Democracy and the Limits Democratization. In David Held (ed). Prospects for Democracy; North, South, East, West. Stanford: Stanford University Press.

Dahl, R. A. (1978). Modern Political Analysis. New Delhi: Prentice Hall of India.

Demetriou, C. (2009). The Realist Approach to Explanatory Mechanisms in Social Science: More than a heuristic? Philosophy of the Social Science, 39, 440-464.

Diamond, L., Juan L. \& Seymour M. L. (1990). Political and developing Countries: Comparing Experience with Democracy. Boulder, Colorado: Lynne Rienner.

Fattah, A. (2008). Konflik Pasca Pilkada: Kasus Depok. Jurnal Poelitik, 1(1), 1-18.

Goodwin-Gill, G. S. (1999). Election Jurdil: Experience and International Standard (Free and Fair Election: International Standards and Practices). Translation by Nurhasan. Jakarta: PIRAC cooperation with The Asia Foundation.

Hakim, M. Z. (2011). Democracy in the elections in Indonesia. UNM Humanist Journal, 12(2), 1-12.

Hardiman, F. B. (2009). Deliberative Democracy. Yogyakarta: Canisius.

Lay, C. (2007). Direct elections and Deepening Democracy. Journal of Social and Political Science, 11(1), 63-92.

Mayo, H. B. (1960). An Introduction to Democratic Theory. New York: Oxford University Press.

Nas, J. (2015). Konflik Elite di Sulawesi Selatan: Analisis Pemerintahan dan Politik Lokal. Makassar: Lembaga Penerbitan Unhas.

Prihatmoko, J. J. (2005). Pemilihan Kepala Daerah Langsung. Yogyakarta. Pustaka Pelajar.

Sartori, G. (1987). The Theory of Democracy Revisited. Chatham, NJ: Chatham House Publishers.

Strong, C. F. (1973). Modern Political Constitution. London: London: Sidwick \& Jackson.

Tilly, C. (2000). Processes and Mechanisms of Democratization. Sociological Theory, 18(1). Published by: American Sociological Association. 
Tjiptabudy, J. (2014). Reorganizing the Election and Election Law Enforcement. Faculty of Law, University of Pattimura.

Winarno. (2007). New Paradigm for Civic Education. Jakarta: PT. Earth Literacy.

\section{Website}

Evolution of Regional Head Election System in Indonesia. Source: http://politik.news.viva.co.id/news/read/542375-evolusi-sistem-pemilihan-kepala-daerah-diindonesia [Accessed: January 30, 2016].

http://www.kompasiana.com/rizahakiki/tanggapan-terhadap-ide-peradilan-khususpemilu_551fbb90a333119941b65b64 [Accessed on February 13, 2016] 